\title{
Humanitarian evidence summary
}

\section{No.12}

\author{
Luke Kelly \\ University of Manchester \\ 08 March 2021
}

This is the 12th monthly Humanitarian Evidence Summary (HUMES) to signpost FCDO and other UK government departments to the latest relevant evidence and discourse on humanitarian action to inform and support their response. It is the result of 1 day of work per month and is not intended to be a comprehensive summary of available evidence on humanitarian action but aims to make original documents easily accessible to decision-makers that, if relevant to them, they could refer to before making decisions.

\section{Enhancing protection and humanitarian access}

\begin{tabular}{|c|c|c|c|c|}
\hline $\begin{array}{l}\text { Publication } \\
\text { date }\end{array}$ & Title/URL & $\begin{array}{l}\text { Author(s)/Journal/Publication } \\
\text { type }\end{array}$ & Summary & $\begin{array}{l}\text { HoP } \\
\text { Top } \\
\text { reads }\end{array}$ \\
\hline Feb 2021 & $\begin{array}{l}\text { The Last Straw: } \\
\text { How Chemical } \\
\text { Weapons } \\
\text { Impact Women } \\
\text { and Break } \\
\text { Communities }\end{array}$ & $\begin{array}{l}\text { Inju El Bakry and Tobias } \\
\text { Schneider; GPPI; web page. }\end{array}$ & $\begin{array}{l}\text { Research on the effects of } \\
\text { chemical weapons on } \\
\text { women and children in } \\
\text { Syria. Based on data on } \\
\text { chemical attacks, gender- } \\
\text { disaggregated casualties, } \\
\text { and interviews, the report } \\
\text { provides data and shows } \\
\text { the physical and mental } \\
\text { effects, as well as the } \\
\text { effects on women's roles, } \\
\text { forced migration and } \\
\text { community resilience. }\end{array}$ & \\
\hline Feb 2021 & $\begin{array}{l}\text { Speaking Out } \\
\text { Srebrenica } \\
\text { Podcast }\end{array}$ & MSF; podcast & $\begin{array}{l}\text { Discusses the dilemmas } \\
\text { faced by MSF around the } \\
\text { Srebrenica massacres. }\end{array}$ & \\
\hline 4 March & $\begin{array}{l}\text { From 'It Rarely } \\
\text { Happens' to 'It's }\end{array}$ & $\begin{array}{l}\text { Helen Touquet et al.; Journal } \\
\text { of Humanitarian Affairs; }\end{array}$ & $\begin{array}{l}\text { Discusses ten } \\
\text { misconceptions on sexual }\end{array}$ & \\
\hline
\end{tabular}




\begin{tabular}{|c|c|c|c|}
\hline 2021 & $\begin{array}{l}\text { Worse for Men': } \\
\text { Dispelling } \\
\text { Misconceptions } \\
\text { about Sexual } \\
\text { Violence } \\
\text { against Men } \\
\text { and Boys in } \\
\text { Conflict and } \\
\text { Displacement }\end{array}$ & article & $\begin{array}{l}\text { violence against men and } \\
\text { boys in conflict and } \\
\text { displacement, and } \\
\text { implications for } \\
\text { policymakers. }\end{array}$ \\
\hline $\begin{array}{l}\text { March } \\
2021\end{array}$ & $\begin{array}{l}\text { ICRC } \\
\text { Engagement } \\
\text { with Non-State } \\
\text { Armed Groups } \\
\text { Why, how, for } \\
\text { what purpose, } \\
\text { and other } \\
\text { salient issues }\end{array}$ & ICRC; position paper & $\begin{array}{l}\text { The paper outlines reasons } \\
\text { for engaging with non-state } \\
\text { armed groups (NSAGs), } \\
\text { the legal basis for } \\
\text { engagement, the role of } \\
\text { NSAGs in humanitarian } \\
\text { contexts and their features, } \\
\text { and ways that the ICRC } \\
\text { can engage NASGs with } \\
\text { international humanitarian } \\
\text { law (IHL). }\end{array}$ \\
\hline $\begin{array}{l}22 \text { Feb } \\
2021\end{array}$ & $\begin{array}{l}\text { The } \\
\text { Effectiveness of } \\
\text { Women and } \\
\text { Girls Safe } \\
\text { Spaces: A } \\
\text { Systematic } \\
\text { Review of } \\
\text { Evidence to } \\
\text { Address } \\
\text { Violence } \\
\text { Against Women } \\
\text { and Girls in } \\
\text { Humanitarian } \\
\text { Contexts }\end{array}$ & $\begin{array}{l}\text { Lindsay Starck et al; } \\
\text { Trauma, Violence \& Abuse; } \\
\text { article }\end{array}$ & $\begin{array}{l}\text { The article found only } 7 \\
\text { studies of women and girls } \\
\text { safe spaces (WGSS) } \\
\text { programmes. It found that } \\
\text { 'while none of the studies } \\
\text { reported reductions in } \\
\text { exposure to or incidence of } \\
\text { VAWG among program } \\
\text { participants, three } \\
\text { evaluations demonstrated } \\
\text { moderate improvements in } \\
\text { psychosocial well-being, } \\
\text { social support, and } \\
\text { attitudes toward rites of } \\
\text { passage'. It emphasises } \\
\text { the need for more rigorous } \\
\text { evidence. }\end{array}$ \\
\hline Feb 2021 & $\begin{array}{l}\text { Gap Analysis } \\
\text { Of Gender- } \\
\text { Based Violence } \\
\text { In Humanitarian } \\
\text { Settings: A } \\
\text { Global }\end{array}$ & ELRHA; literature review & $\begin{array}{l}\text { Analyses humanitarian } \\
\text { guidelines and activities to } \\
\text { identify gaps in gender- } \\
\text { based violence work. It } \\
\text { finds a lack of prioritisation, } \\
\text { commitment and }\end{array}$ \\
\hline
\end{tabular}




\begin{tabular}{|c|c|c|c|}
\hline & Consultation & & $\begin{array}{l}\text { accountability; a lack of } \\
\text { specialist staff and funding. } \\
\text { The growth of GBV during } \\
\text { covid and reduced funding } \\
\text { are likely to make things } \\
\text { worse, although the report } \\
\text { points to important training } \\
\text { initiatives and models. }\end{array}$ \\
\hline $\begin{array}{l}\text { March } \\
2021\end{array}$ & $\begin{array}{l}\text { Breaking the } \\
\text { silence: } \\
\text { Lessons from } \\
\text { humanitarian } \\
\text { access } \\
\text { negotiations } \\
\text { under counter- } \\
\text { terrorism } \\
\text { legislation in } \\
\text { north-western } \\
\text { Syria }\end{array}$ & $\begin{array}{l}\text { Lena Schellhammer; Centre } \\
\text { for Humanitarian Action; } \\
\text { article }\end{array}$ & $\begin{array}{l}\text { The article is based on } \\
\text { interviews with NGO staff in } \\
\text { Turkey/Syria. It focuses on } \\
\text { humanitarian access } \\
\text { negotiations with Hay'at } \\
\text { Tahrīr al-Shām (HTS) and } \\
\text { its local governance } \\
\text { institution, the Syrian } \\
\text { Salvation Government } \\
\text { (SSG), in north-western } \\
\text { Syria. It argues counter- } \\
\text { terrorism measures lead to } \\
\text { a culture of silence and } \\
\text { reduced bargaining power; } \\
\text { and problematic strategies } \\
\text { such as using } \\
\text { intermediaries and threats } \\
\text { to suspend aid. }\end{array}$ \\
\hline
\end{tabular}

\section{Needs assessment and analysis}

\begin{tabular}{|l|l|l|l|l|}
\hline $\begin{array}{l}\text { Publication } \\
\text { date }\end{array}$ & Title/URL & $\begin{array}{l}\text { Author(s)/Journal/Publication } \\
\text { type }\end{array}$ & Summary & $\begin{array}{l}\text { Top } \\
\text { reads }\end{array}$ \\
\hline 2021 & $\begin{array}{l}\text { Economics, } \\
\text { social status } \\
\text { and gender } \\
\text { relations: } \\
\text { what makes } \\
\text { households } \\
\text { 'female- }\end{array}$ & $\begin{array}{l}\text { Simon Levine and Irina } \\
\text { note }\end{array}$ & $\begin{array}{l}\text { Asks aid agencies to } \\
\text { question whether the } \\
\text { category of 'female-headed } \\
\text { households' (FHH) is always } \\
\text { useful or accurate. It is } \\
\text { based on research in } \\
\text { Somalia. Findings include } \\
\text { that many FHH are married, }\end{array}$ & \\
\hline
\end{tabular}




\begin{tabular}{|c|c|c|c|}
\hline & $\begin{array}{l}\text { headed' in } \\
\text { Somalia? }\end{array}$ & & $\begin{array}{l}\text { contrary to assumptions; } \\
\text { many women headed } \\
\text { households on the basis of } \\
\text { economic power; Somalia } \\
\text { women do not fit the } \\
\text { presumed 'vulnerability' } \\
\text { profile of FHH. It suggests } \\
\text { needs assessments should } \\
\text { carefully justify their } \\
\text { targeting criteria. }\end{array}$ \\
\hline $\begin{array}{l}\text { March } \\
2020\end{array}$ & $\begin{array}{l}\text { Nutrition } \\
\text { Exchange } 13\end{array}$ & $\begin{array}{l}\text { Nutrition Exchange; journal } \\
\text { issue }\end{array}$ & $\begin{array}{l}\text { Reports from the } 2019 \\
\text { Scaling Up Nutrition } \\
\text { conference. }\end{array}$ \\
\hline Feb 2020 & $\begin{array}{l}\text { Review And } \\
\text { Assessment } \\
\text { Of MHPSS } \\
\text { Intervention } \\
\text { Research In } \\
\text { Humanitarian } \\
\text { Settings }\end{array}$ & & $\begin{array}{l}\text { A review of mental health } \\
\text { and psychosocial support } \\
\text { (MHPSS) research } \\
\text { generated since } 2010 \text {. It } \\
\text { finds an increase in research } \\
\text { overall, but gaps in evidence } \\
\text { on outcomes for children and } \\
\text { family based interventions, } \\
\text { or long-term impacts. It } \\
\text { found some evidence of } \\
\text { increased uptake, but limited } \\
\text { changes in national } \\
\text { government policy. }\end{array}$ \\
\hline
\end{tabular}

\section{Accountability to affected populations}

\begin{tabular}{|l|l|l|l|l|}
\hline $\begin{array}{l}\text { Publication } \\
\text { date }\end{array}$ & Title/URL & $\begin{array}{l}\text { Author(s)/Journal/Publication } \\
\text { type }\end{array}$ & Summary & $\begin{array}{l}\text { Top } \\
\text { reads }\end{array}$ \\
\hline 2021 & $\begin{array}{l}\text { New Ebola } \\
\text { outbreaks: } \\
\text { putting } \\
\text { context and } \\
\text { community } \\
\text { first }\end{array}$ & $\begin{array}{l}\text { Kerrie Holloway and Marc } \\
\text { DuBois; ODI HPG; blog }\end{array}$ & $\begin{array}{l}\text { Emphasises that } \\
\text { international responses to } \\
\text { the new Ebola outbreaks } \\
\text { should be owned by the host } \\
\text { states and grounded in local } \\
\text { health structures. } \\
\text { Interventions should be } \\
\text { grounded in context-specific }\end{array}$ & \\
\hline
\end{tabular}




\begin{tabular}{|l|l|}
$\mid$\begin{tabular}{l|l|} 
understandings of 'culture', \\
the effects of previous \\
interventions, strengthen \\
local health structures, pay \\
adequate attention to other \\
diseases and needs, and \\
engage with communities.
\end{tabular} \\
\hline
\end{tabular}

\section{Cash programming}

\begin{tabular}{|c|c|c|c|c|}
\hline $\begin{array}{l}\text { Publication } \\
\text { date }\end{array}$ & Title/URL & $\begin{array}{l}\text { Author(s)/Journal/Publication } \\
\text { type }\end{array}$ & Summary & Top \\
\hline $\begin{array}{l}23 \text { Feb } \\
2021\end{array}$ & $\begin{array}{l}\text { Covid-19 and the } \\
\text { future of digital } \\
\text { humanitarianism }\end{array}$ & $\begin{array}{l}\text { Overseas Development } \\
\text { Institute; webinar }\end{array}$ & $\begin{array}{l}\text { Discusses the potential } \\
\text { of digital tools based on } \\
\text { evidence from covid-19, } \\
\text { and the possibility of } \\
\text { overcoming digital } \\
\text { divides, new risks, and } \\
\text { engaging with other } \\
\text { actors. }\end{array}$ & \\
\hline $\begin{array}{l}2 \text { March } \\
2021\end{array}$ & $\begin{array}{l}\text { Cashless cash: } \\
\text { financial inclusion } \\
\text { or surveillance } \\
\text { humanitarianism? }\end{array}$ & $\begin{array}{l}\text { Pierrick Devidal; ICRC Law } \\
\text { \& Policy; blog }\end{array}$ & $\begin{array}{l}\text { Argues that digital cash } \\
\text { has the same benefits } \\
\text { as physical cash, but } \\
\text { brings distinct risks. } \\
\text { Digital payment } \\
\text { mechanisms are not } \\
\text { provided by } \\
\text { humanitarian actors, and } \\
\text { may not be neutral in } \\
\text { conflict situations, which } \\
\text { may jeopardise the } \\
\text { neutrality of any cash } \\
\text { delivered through them. } \\
\text { They may also threaten } \\
\text { humanitarian } \\
\text { independence by } \\
\text { controlling the } \\
\text { parameters of payments. } \\
\text { They will work under } \\
\text { different legal } \\
\text { frameworks not always }\end{array}$ & \\
\hline
\end{tabular}




\begin{tabular}{|c|c|c|c|}
\hline & & & $\begin{array}{l}\text { congruent with } \\
\text { impartiality. }\end{array}$ \\
\hline $\begin{array}{l}18 \text { Feb } \\
2021\end{array}$ & $\begin{array}{l}\text { The social } \\
\text { meaning of } \\
\text { money: } \\
\text { Multidimensional } \\
\text { implications of } \\
\text { humanitarian } \\
\text { cash and voucher } \\
\text { assistance }\end{array}$ & $\begin{array}{l}\text { Birte Vogel, Kristina } \\
\text { Tschunkert and Isabelle } \\
\text { Schläpfer; Disasters; journal } \\
\text { article }\end{array}$ & $\begin{array}{l}\text { Argues that } \\
\text { organisations } \\
\text { implementing cash } \\
\text { transfers should } \\
\text { consider the } \\
\text { 'multidimensional socio- } \\
\text { economic, political, and } \\
\text { socio-cultural } \\
\text { dimensions of money' - it } \\
\text { points to perceptions of } \\
\text { relative deprivation; } \\
\text { changes in local } \\
\text { markets; informal beliefs } \\
\text { about what aid should } \\
\text { be spent on in } \\
\text { communities; disputes } \\
\text { over targeting }\end{array}$ \\
\hline
\end{tabular}

\section{Managing risk better, preparedness and anticipation}

\begin{tabular}{|c|c|c|c|c|}
\hline $\begin{array}{l}\text { Publication } \\
\text { date }\end{array}$ & Title/URL & $\begin{array}{l}\text { Author(s)/Journal/Publication } \\
\text { type }\end{array}$ & Summary & rop \\
\hline Feb 2021 & $\begin{array}{l}\text { Findings from } \\
\text { the second } \\
\text { research } \\
\text { wave of the } \\
\text { Independent } \\
\text { Evaluation of } \\
\text { the FCDO } \\
\text { Development } \\
\text { Impact Bonds } \\
\text { Pilot } \\
\text { Programme }\end{array}$ & $\begin{array}{l}\text { Kay Lau, James Ronicle, } \\
\text { Sara Rizzo, Alma Agusti } \\
\text { Strid, Daniel Silver, Jennifer } \\
\text { Armitage and Zachary } \\
\text { Levey; FCDO; evaluation. }\end{array}$ & $\begin{array}{l}\text { Evaluation of the FCDO's } \\
\text { Development Impact Bonds } \\
\text { (DIBs) pilot programme } \\
\text { (2017-2023). Includes the } \\
\text { ICRC Humanitarian Impact } \\
\text { Bond for Physical } \\
\text { Rehabilitation to fund } \\
\text { rehabilitation centres. A DIB } \\
\text { is a mechanism for drawing } \\
\text { external finance } \\
\text { into payment-by-results } \\
\text { (PbR) projects. It suggests } \\
\text { that DIBs are effective } \\
\text { because of factors including: } \\
\text { a stronger focus on } \\
\text { outcomes, heightened }\end{array}$ & \\
\hline
\end{tabular}




\begin{tabular}{|c|c|c|c|}
\hline & & & $\begin{array}{l}\text { performance management, } \\
\text { external perspectives and } \\
\text { expertise in project } \\
\text { implementation and better } \\
\text { performance because of the } \\
\text { reputational and financial } \\
\text { risks for stakeholders. }\end{array}$ \\
\hline Feb 2021 & $\begin{array}{l}\text { The State of } \\
\text { Open } \\
\text { Humanitarian } \\
\text { Data } 2021\end{array}$ & $\begin{array}{l}\text { Centre for Humanitarian } \\
\text { Data; report }\end{array}$ & $\begin{array}{l}\text { The report outlines how HDX } \\
\text { has expanded its data, but } \\
\text { finds data gaps in countries } \\
\text { experiencing humanitarian } \\
\text { crises. Quantifies } \\
\text { completeness of data for } 27 \\
\text { countries with a } \\
\text { humanitarian response plan, } \\
\text { divided into several } \\
\text { categories. It estimates the } \\
\text { total percentage of complete } \\
\text { data at } 51 \% \text {. }\end{array}$ \\
\hline $\begin{array}{l}5 \text { March } \\
2021\end{array}$ & $\begin{array}{l}\text { How the } \\
\text { integration of } \\
\text { health and } \\
\text { disaster risk } \\
\text { reduction can } \\
\text { set Asia- } \\
\text { Pacific on a } \\
\text { path towards } \\
\text { resilience; } \\
\text { and webinar. }\end{array}$ & UNDRR; blog & $\begin{array}{l}\text { Describes recent } \\
\text { discussions on the need for } \\
\text { disaster risk reduction (DRR) } \\
\text { strategies to integrate health } \\
\text { more, following covid-19. It } \\
\text { notes global frameworks and } \\
\text { guidelines on their } \\
\text { integration, as well as } \\
\text { examples of good practice } \\
\text { from ASEAN. }\end{array}$ \\
\hline $\begin{array}{l}24 \text { Feb } \\
2021\end{array}$ & $\begin{array}{l}\text { Rethinking } \\
\text { disease } \\
\text { preparedness: } \\
\text { incertitude } \\
\text { and } \\
\text { the politics of } \\
\text { knowledge }\end{array}$ & $\begin{array}{l}\text { Melissa Leach et al.; Critical } \\
\text { Public Health; journal article }\end{array}$ & $\begin{array}{l}\text { Academic article suggesting } \\
\text { approaches to disease } \\
\text { preparedness should be } \\
\text { rethought. It is based on } \\
\text { analysis of responses to } \\
\text { Ebola, Nipah, cholera and } \\
\text { covid-19. Findings include } \\
\text { that expert knowledge is } \\
\text { often privileged above local } \\
\text { knowledge, and that models } \\
\text { fail to take into account } \\
\text { uncertainty. Preparedness } \\
\text { should take into account the }\end{array}$ \\
\hline
\end{tabular}




\begin{tabular}{|c|c|c|c|}
\hline & & & $\begin{array}{l}\text { politics of knowledge, the } \\
\text { constructions of } \\
\text { time and space, the } \\
\text { requirements for institutions } \\
\text { and administrations and the } \\
\text { challenges of ethics and } \\
\text { justice. }\end{array}$ \\
\hline $\begin{array}{l}\text { March } \\
2021\end{array}$ & $\begin{array}{l}\text { Post-Covid-19 } \\
\text { Scenarios }\end{array}$ & ACAPs; report & $\begin{array}{l}\text { Three scenarios for the } \\
\text { humanitarian operating } \\
\text { environment in 2021: } \\
\text { Continuing adaptation of } \\
\text { response mechanisms; } \\
\text { existing power dynamics } \\
\text { unchanged (medium } \\
\text { probability); } \\
\text { Increased national influence; } \\
\text { reframed international } \\
\text { support (low probability); } \\
\text { Increased national control } \\
\text { and severely reduced } \\
\text { international influence and } \\
\text { support (negligible) }\end{array}$ \\
\hline $\begin{array}{l}\text { March } \\
2021\end{array}$ & $\begin{array}{l}\text { The global } \\
\text { financial } \\
\text { burden of } \\
\text { humanitarian } \\
\text { disasters: } \\
\text { Leveraging } \\
\text { GDP variation } \\
\text { in the age of } \\
\text { climate } \\
\text { change }\end{array}$ & $\begin{array}{l}\text { Topher L McDougal and } \\
\text { John H Patterson; } \\
\text { International Journal of } \\
\text { Disaster Risk Reduction }\end{array}$ & $\begin{array}{l}\text { Estimates the global } \\
\text { spending burden of } \\
\text { humanitarian response, } \\
\text { including domestic spending } \\
\text { on which there is little data, } \\
\text { at } \$ 367 \mathrm{bn} \text { per year. Also } \\
\text { finds that 'each } 1^{\circ} \mathrm{C} \text { rise in } \\
5 \text {-year temperature } \\
\text { anomalies would require an } \\
\text { annual } 3.1 \%(95 \% \mathrm{Cl} \text { : } \\
0.18 \%-6.01 \%) \text { rise in } \\
\text { humanitarian spending'. }\end{array}$ \\
\hline
\end{tabular}




\begin{tabular}{|c|c|c|c|c|}
\hline $\begin{array}{l}\text { Publication } \\
\text { date }\end{array}$ & Title/URL & $\begin{array}{l}\text { Author(s)/Journal/Publication } \\
\text { type }\end{array}$ & Summary & Top \\
\hline $\begin{array}{l}8 \text { March } \\
2021\end{array}$ & $\begin{array}{l}\text { Lancet } \\
\text { Series: } \\
\text { Maternal and } \\
\text { Child } \\
\text { Undernutrition } \\
\text { Progress }\end{array}$ & $\begin{array}{l}\text { Various authors, Lancet } \\
\text { Journal }\end{array}$ & $\begin{array}{l}\text { Follow up to } 2008 / 13 \text { Series } \\
\text { concluding that } \\
\text { undernutrition remains a } \\
\text { major global health concern, } \\
\text { particularly as gains may be } \\
\text { offset by COVID-19. It finds } \\
\text { previously highlighted } \\
\text { interventions continue to be } \\
\text { effective at reducing } \\
\text { stunting, micronutrient } \\
\text { deficiencies, and child } \\
\text { deaths and emphasizes the } \\
\text { importance of delivering } \\
\text { nutrition interventions within } \\
\text { the first } 1,000 \text { days. } \\
\text { However, delivery has } \\
\text { lagged behind the evidence } \\
\text { and further financing is } \\
\text { needed. }\end{array}$ & \\
\hline $\begin{array}{l}\text { March } \\
2021\end{array}$ & $\begin{array}{l}\text { Forced } \\
\text { Migration } \\
\text { Review 66: } \\
\text { Mental health } \\
\text { and } \\
\text { psychosocial } \\
\text { support, Data } \\
\text { and } \\
\text { displacement, } \\
\text { Missing } \\
\text { migrants }\end{array}$ & $\begin{array}{l}\text { Forced Migration Review; } \\
\text { journal issue }\end{array}$ & $\begin{array}{l}\text { Articles discusse mental } \\
\text { health and psychosocial } \\
\text { support (MHPSS) in various } \\
\text { contexts of displacement. } \\
\text { Also includes features on } \\
\text { data and displacement and } \\
\text { missing migrants. }\end{array}$ & \\
\hline $\begin{array}{l}11 \text { Feb } \\
2021\end{array}$ & $\begin{array}{l}\text { Humanitarian } \\
\text { engagement } \\
\text { in social } \\
\text { protection: } \\
\text { implications } \\
\text { for principled } \\
\text { humanitarian } \\
\text { action }\end{array}$ & $\begin{array}{l}\text { Cristina Quijano Carrasco; } \\
\text { ICRC Law \& policy; blog }\end{array}$ & $\begin{array}{l}\text { Considers the challenges } \\
\text { arising when humanitarian } \\
\text { actors engage with social } \\
\text { protection systems. In } \\
\text { particular, collaboration with } \\
\text { national governments and } \\
\text { others, and the sharing of } \\
\text { data, create risks. These } \\
\text { include the possibility that }\end{array}$ & \\
\hline
\end{tabular}




\begin{tabular}{|c|c|c|c|}
\hline & & & $\begin{array}{l}\text { governments may use data } \\
\text { to vet recipients or financial } \\
\text { institutions may sell personal } \\
\text { data. }\end{array}$ \\
\hline $\begin{array}{l}5 \text { March } \\
2021\end{array}$ & $\begin{array}{l}\text { Joining } \\
\text { Forces to } \\
\text { Combat } \\
\text { Protracted } \\
\text { Crises: } \\
\text { Humanitarian } \\
\text { and } \\
\text { Development } \\
\text { Support for } \\
\text { Water and } \\
\text { Sanitation } \\
\text { Providers in } \\
\text { the Middle } \\
\text { East and } \\
\text { North Africa }\end{array}$ & $\begin{array}{l}\text { World Bank; ICRC; UNICEF; } \\
\text { report. }\end{array}$ & $\begin{array}{l}\text { Explores problems relating } \\
\text { to water and sanitation in } \\
\text { protracted crises in the } \\
\text { region, and how } \\
\text { humanitarian and } \\
\text { development actors can } \\
\text { cooperate to address them. }\end{array}$ \\
\hline $\begin{array}{l}25 \text { Feb } \\
2021\end{array}$ & $\begin{array}{l}\text { Inter-Agency } \\
\text { Toolkit } \\
\text { Preventing } \\
\text { and } \\
\text { Responding } \\
\text { To Child } \\
\text { Labour In } \\
\text { Humanitarian } \\
\text { Action }\end{array}$ & $\begin{array}{l}\text { Alliance for Child Protection } \\
\text { in Humanitarian Action; } \\
\text { Toolkit }\end{array}$ & $\begin{array}{l}\text { A toolkit on ways to prevent } \\
\text { and respond to child labour } \\
\text { in humanitarian } \\
\text { interventions. }\end{array}$ \\
\hline $\begin{array}{l}25 \text { Feb } \\
2021\end{array}$ & $\begin{array}{l}\text { The Global } \\
\text { Cost of } \\
\text { Inclusive } \\
\text { Refugee } \\
\text { Education }\end{array}$ & World Bank; UNHCR & $\begin{array}{l}\text { Provides estimates on what } \\
\text { it would cost to provide } \\
\text { refugee education for host } \\
\text { countries. }\end{array}$ \\
\hline $\begin{array}{l}25 \text { Feb } \\
2021\end{array}$ & $\begin{array}{l}\text { The grand } \\
\text { scheme: } \\
\text { power and } \\
\text { politics in the } \\
\text { climate crisis }\end{array}$ & $\begin{array}{l}\text { Malvika Verma; ICRC Law \& } \\
\text { Policy blog }\end{array}$ & $\begin{array}{l}\text { Argues that disaster } \\
\text { reduction and resilience } \\
\text { interventions in contexts } \\
\text { where climate change has } \\
\text { exacerbated risks should } \\
\text { consider broader power } \\
\text { dynamics underlying these }\end{array}$ \\
\hline
\end{tabular}




\begin{tabular}{|l|l|l|l|l|}
\hline & & $\begin{array}{l}\text { risks. This requires long- } \\
\text { term engagement with states } \\
\text { and other actors. }\end{array}$ \\
\hline
\end{tabular}

\section{Other}

\begin{tabular}{|c|c|c|c|c|}
\hline $\begin{array}{l}\text { Publication } \\
\text { date }\end{array}$ & Title/URL & $\begin{array}{l}\text { Author(s)/Journal/Publication } \\
\text { type }\end{array}$ & Summary & Top \\
\hline 3 Mar 2021 & $\begin{array}{l}\text { Handbook for } \\
\text { the UN Resident } \\
\text { and } \\
\text { Humanitarian } \\
\text { Coordinator }\end{array}$ & $\begin{array}{l}\text { Interagency Standing } \\
\text { Committee Guidance }\end{array}$ & $\begin{array}{l}\text { A reference for RCHCs } \\
\text { and others on the } \\
\text { normative framework for } \\
\text { humanitarian action and } \\
\text { the operational } \\
\text { approaches, coordination } \\
\text { structures, and available } \\
\text { tools and services that } \\
\text { facilitate humanitarian } \\
\text { assistance. }\end{array}$ & \\
\hline $\begin{array}{l}13 \text { Feb } \\
2021\end{array}$ & $\begin{array}{l}\text { Foreign Aid Is } \\
\text { Having a } \\
\text { Reckoning }\end{array}$ & $\begin{array}{l}\text { New York Times; editorial } \\
\text { opinion }\end{array}$ & $\begin{array}{l}\text { The article discusses } \\
\text { criticism of aid to Africa, } \\
\text { noting limited 'localisation' } \\
\text { of aid, 'white saviour } \\
\text { mentalities' in aid, and the } \\
\text { persistence of trade } \\
\text { barriers and debt. It } \\
\text { argues that Black Lives } \\
\text { Matter has prompted } \\
\text { many to reevaluate how } \\
\text { they give aid, but that so } \\
\text { far this effect has been } \\
\text { greater among private } \\
\text { philanthropists than } \\
\text { governments. }\end{array}$ & \\
\hline $\begin{array}{l}25 \text { Feb } \\
2021\end{array}$ & $\begin{array}{l}\text { When throwing } \\
\text { evidence and } \\
\text { facts is not } \\
\text { enough. How } \\
\text { Change }\end{array}$ & Oxfam blogs & $\begin{array}{l}\text { Argues that evidence is } \\
\text { not always the best way } \\
\text { to effect changes in the } \\
\text { humanitarian system. } \\
\text { Discusses where }\end{array}$ & \\
\hline
\end{tabular}




\begin{tabular}{|l|l|l|l|l|}
\cline { 2 - 4 } & $\begin{array}{l}\text { Happens in the } \\
\text { Humanitarian } \\
\text { System }\end{array}$ & $\begin{array}{l}\text { evidence is and is not } \\
\text { effective. }\end{array}$ & \\
\hline Feb 2021 & $\begin{array}{l}\text { Trumanitarian: } \\
\text { Great Leap } \\
\text { Sideways }\end{array}$ & $\begin{array}{l}\text { Lars Peter Nissen, Fergus } \\
\text { Thomas; Podcast }\end{array}$ & $\begin{array}{l}\text { Explores the vision, } \\
\text { evolution and value of the } \\
\text { H2H network }\end{array}$ & \\
\hline $\begin{array}{l}19 \text { Feb } \\
2021\end{array}$ & $\begin{array}{l}\text { Rethinking } \\
\text { Humanitarianism } \\
\text { podcast }\end{array}$ & $\begin{array}{l}\text { Heba Aly and Jeremy } \\
\text { Konyndyk }\end{array}$ & $\begin{array}{l}\text { On 'blue sky thinking' in } \\
\text { the sector. }\end{array}$ & \\
\hline
\end{tabular}

\section{Resource Hubs}

\begin{tabular}{|c|c|c|}
\hline Title/URL & Author/Organisation & Summary \\
\hline $\begin{array}{l}\text { Covid-19 and } \\
\text { Humanitarian Crises }\end{array}$ & $\begin{array}{l}\text { Johns Hopkins Center for } \\
\text { Humanitarian Health, } \\
\text { Health in Humanitarian } \\
\text { Crises Centre, London } \\
\text { School of Hygiene and } \\
\text { Tropical Medicine and } \\
\text { Geneva Centre of } \\
\text { Humanitarian Studies, } \\
\text { The Graduate Institute of } \\
\text { International and } \\
\text { Development Studies and } \\
\text { the University of Geneva }\end{array}$ & $\begin{array}{l}\text { Website for the exchange of } \\
\text { field-based COVID-19 } \\
\text { programme adaptations and } \\
\text { innovations. }\end{array}$ \\
\hline $\begin{array}{l}\text { Covid- } 19 \text { Mobility Impact } \\
\text { Reports }\end{array}$ & UN IOM & $\begin{array}{l}\text { Frequently updated reports on } \\
\text { migration restrictions. }\end{array}$ \\
\hline $\begin{array}{l}\text { IDMC Internal } \\
\text { Displacement Updates }\end{array}$ & $\begin{array}{l}\text { Internal displacement } \\
\text { monitoring centre }\end{array}$ & $\begin{array}{l}\text { Global data on internal } \\
\text { displacement }\end{array}$ \\
\hline ACAPS Crisis in Sight & ACAPS & $\begin{array}{l}\text { Global overview of crisis, } \\
\text { including covid and conflict; as } \\
\text { well as access constraints. }\end{array}$ \\
\hline
\end{tabular}




\begin{tabular}{|c|c|c|}
\hline $\begin{array}{l}\text { CVA and COVID-19: } \\
\text { resources, guidance, } \\
\text { events and questions }\end{array}$ & CaLP & $\begin{array}{l}\text { Guidance and resources on } \\
\text { covid and cash transfers }\end{array}$ \\
\hline $\begin{array}{l}\text { IASC: COVID-19 } \\
\text { Outbreak Readiness and } \\
\text { Response guidance }\end{array}$ & $\begin{array}{l}\text { Inter-Agency Standing } \\
\text { Committee }\end{array}$ & $\begin{array}{l}\text { IASC principles and protocols } \\
\text { adapted to covid- } 19\end{array}$ \\
\hline $\begin{array}{l}\text { OCHA } \\
\text { COVID19 Resource } \\
\text { Material }\end{array}$ & $\begin{array}{l}\text { Office for the Coordination } \\
\text { of Humanitarian Affairs }\end{array}$ & $\begin{array}{l}\text { A wide range of guidance and } \\
\text { resources from WHO, IASC, the } \\
\text { EU, IFRF and others, as well as } \\
\text { country-specific information. }\end{array}$ \\
\hline $\begin{array}{l}\text { Humanitarian Data } \\
\text { Exchange: COVID-19 } \\
\text { Pandemic in Locations } \\
\text { with a Humanitarian } \\
\text { Response }\end{array}$ & $\begin{array}{l}\text { Humanitarian Data } \\
\text { Exchange (HDX) }\end{array}$ & $\begin{array}{l}\text { Global data on infections and } \\
\text { deaths; a list of data sets on } \\
\text { cases and prevention/mitigation } \\
\text { measures. }\end{array}$ \\
\hline $\begin{array}{l}\text { Humanitarian Data } \\
\text { Exchange: Government } \\
\text { Measures Dataset }\end{array}$ & $\begin{array}{l}\text { Humanitarian Data } \\
\text { Exchange (HDX) }\end{array}$ & $\begin{array}{l}\text { Global data on government } \\
\text { covid-19 measures under } 5 \\
\text { categories: Social distancing; } \\
\text { Movement restrictions; Public } \\
\text { health measures; Social and } \\
\text { economic measures; } \\
\text { Lockdowns. }\end{array}$ \\
\hline $\begin{array}{l}\text { IEG Lesson Library: } \\
\text { Evaluative Resources and } \\
\text { Evidence to inform the } \\
\text { COVID-19 Response }\end{array}$ & $\begin{array}{l}\text { World Bank Independent } \\
\text { Evaluation Group }\end{array}$ & $\begin{array}{l}\text { A library of Evaluative Resources } \\
\text { and Evidence to inform the } \\
\text { COVID-19 Response }\end{array}$ \\
\hline $\begin{array}{l}\text { Relief Web: regional topic } \\
\text { pages for Covid-19 } \\
\text { and global topic pages }\end{array}$ & Relief Web & $\begin{array}{l}\text { Regional and global reports and } \\
\text { resources on humanitarian } \\
\text { needs and response. }\end{array}$ \\
\hline $\begin{array}{l}\text { IASC Accountability and } \\
\text { Inclusion Resources }\end{array}$ & Inter-Agency Standing & A library of resources on \\
\hline
\end{tabular}




\begin{tabular}{|l|l|l|}
\hline Portal & Committee & accountability and inclusion. \\
\hline $\begin{array}{l}\text { Attacked and Threatened: } \\
\text { Health care targeted in } \\
\text { conflict and COVID-19 }\end{array}$ & Insecurity Insight & $\begin{array}{l}\text { Map of violence and threats } \\
\text { against health care across the } \\
\text { world. }\end{array}$ \\
\hline
\end{tabular}

\section{Suggested citation}

Kelly, L. (2021). Monthly Humanitarian Evidence Summary No.12. K4D Helpdesk Report. Brighton, UK: Institute of Development Studies. DOI: 10.19088/K4D.2021.031

\section{Methodology}

Given the wide range of topics covered, this monthly summary includes guidelines, blogs, news articles, dashboards, data, and editorials, in addition to policy and academic literature. The sources included are found through searches of academic literature, humanitarian think tanks, resource hubs and NGO websites. The searches are restricted to articles published in the previous month, in English. This is complemented by email recommendations from DFID advisors and leading experts. This is trial and error approach, which will be refined and changed over the coming weeks. If you have literature to include in the weekly summary, please email - luke.kelly@manchester.ac.uk.

\section{About this report}

The monthly Humanitarian Evidence Summaries are not intended to replace professional advice and the researcher or the $K 4 D$ consortium cannot be held responsible for any decisions made on the basis of the summaries alone.

K4D services are provided by a consortium of leading organisations working in international development, led by the Institute of Development Studies (IDS), with Education Development Trust, Itad, University of Leeds Nuffield Centre for International Health and Development, Liverpool School of Tropical Medicine (LSTM), University of Birmingham International Development Department (IDD) and the University of Manchester Humanitarian and Conflict Response Institute (HCRI).

This humanitarian evidence summary was prepared for the UK Government's Foreign, Commonwealth and Development Office (FCDO) and its partners in support of pro-poor programmes. Except where otherwise stated, it is licensed for non-commercial purposes under the terms of the Open Government Licence v3.O. K4D cannot be held responsible for errors, omissions or any consequences arising from the use of information contained in this humanitarian evidence summary. Any views and opinions expressed do not necessarily reflect those of $F C D O, K 4 D$ or any other contributing organisation.

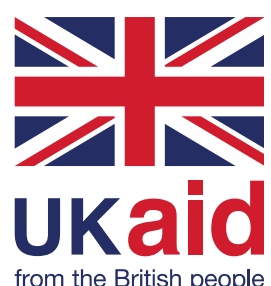

(c) Crown copyright 2021. 